\title{
Towards a Better Understanding of the Molecular Mechanisms Involved in Sunlight-Induced Melanoma
}

\author{
Mandy Williams and Allal Ouhtit* \\ Department of Oncology, Queen's University Belfast, Belfast BT9 7AB, Northern Ireland, UK
}

Received 14 April 2004; revised 17 June 2004; accepted 22 June 2004

\begin{abstract}
Although much less prevalent than its nonmelanoma skin cancer counterparts, cutaneous malignant melanoma (CMM) is the most lethal human skin cancer. Epidemiological and biological studies have established a strong link between lifetime exposure to ultraviolet (UV) light, particularly sunburn in childhood, and the development of melanoma. However, the specific molecular targets of this environmental carcinogen are not known. Data obtained from genetic and molecular studies over the last few years have identified the INK4a/ARF locus as the "gatekeeper" melanoma suppressor, encoding two tumour suppressor proteins in human, $\mathrm{p} 16^{\mathrm{INK} 4 \mathrm{a}}$ and $\mathrm{p} 14^{\mathrm{ARF}}$. Recent developments in molecular biotechnology and research using laboratory animals have made a significant gene breakthrough identifying the components of the $\mathrm{p} 16^{\mathrm{INK} 4 \mathrm{a}} / \mathrm{Rb}$ pathway as the principal and rate-limiting targets of UV radiation actions in melanoma formation. This review summarizes the current knowledge of the molecular mechanisms involved in melanoma development and its relationship to sunlight UV radiation.
\end{abstract}

\section{INTRODUCTION}

Cutaneous malignant melanoma (CMM) is a neoplasm affecting melanocytes, pigmented cells found predominantly in the epidermal layer of the skin [1]. Whilst once a rarity, this type of skin cancer has become a common cancer in the United Kingdom and has increased in incidence faster than any other cancer [2]. Although much less prevalent than its nonmelanoma skin cancer (NMSC) counterparts, it affects a younger population and mortality rates are high for thicker lesions ( 5 years survival for lesions $>3.5 \mathrm{~mm}$ is $48 \%$ ) [3]. CMM constitutes only $2 \%$ of all cancers but it is the seventh commonest cause of cancer death in the UK. In the USA, melanoma will claim 7000 lives per year with a predicted lifetime risk of 1 in 90 [2]. The alarming increase of CMM incidence and its resistance to currently available therapies has emphasized the need to understand the molecular mechanisms involved in its development. Accumulating evidence indicates that the risks of CMM include both genetic and environmental factors [4]. Using well-characterized murine ultraviolet (UV) radiation melanoma model, recent study has provided evidence identifying the components of the retinoblastoma $(\mathrm{Rb})$ pathway as the principal targets of UV mutagenesis in melanoma development [5]. In addition to the $\mathrm{Rb}$ pathway, activation of the Ras-Raf-MAPK signalling pathway is linked to CMM development [6]. This review will focus on examining the relationship between UV and the recent findings in the molecular mechanisms of melanoma development.

\section{CYTOGENETIC STUDIES}

Cytogenetic studies on melanoma families have been meticulously carried out to find chromosome band regions of $1 \mathrm{p}, 1 \mathrm{q}, 6 \mathrm{q}, 9 \mathrm{p}$, and $11 \mathrm{q}$ as being involved at a significantly increased frequency (reviewed in $[7,8]$ ). 1p has been reported to be structurally abnormal in $82 \%$ of analyzed cases, the largest proportion for any chromosome, and anomalies of chromosome 9 were detected in $46 \%$ of the cases [9]. However, the chromosome band region 9p21 was disrupted in premalignant atypical nevi and early primary melanomas, raising the possibility that the genes encoded at 9p21 are important in the pathogenesis and progression of early malignant melanomas. The melanocyte initially becomes dysplastic then has a superficial spreading phase or the radial growth phase, followed by the vertical growth phase when tumour cells invade the dermis [1]. Studies of melanoma families have identified two genes predisposing to melanoma, CDKN2A (INK4a/ARF) and CDK4 located at 9p21 and 12q13, respectively (reviewed in [10]). The loss of the INK4a/ARF locus (seen in $50 \%$ of melanomas), along with activation of the BRAF mutation, is considered the most common genetic lesion in human melanoma. This gene is mutated in a large majority of melanoma cell lines, as well as in many uncultured melanoma cells and in the germline of melanoma kindreds [10].

The CDKN2A (INK4a/ARF) locus mapping to chromosome 9p21 encodes for tumour suppressor genes which are strongly associated with familial melanoma and 


\begin{tabular}{|l|l|l|l|}
\hline $\mathrm{E} 1 \beta$ & $\mathrm{E} 1 \alpha$ & $\mathrm{E} 2$ & $\mathrm{E} 3$ \\
\hline & $\mathrm{P} 16^{\mathrm{INK} 4 \mathrm{~A}} \longrightarrow$ \\
$\longleftarrow \mathrm{P} 14^{\mathrm{ARF}} \longrightarrow$ & $\longleftarrow$
\end{tabular}

FIgURE 1. The structure of the CDKN2 gene.

altered in $10-60 \%$ of sporadic melanomas $[1,10,11]$. In human, INK4A/ARF encodes two distinct tumour suppressor proteins, the inhibitor of kinase $4 \mathrm{~A}, \mathrm{p} 16^{\mathrm{INK} 4 \mathrm{a}}$ and $\mathrm{p} 14^{\mathrm{ARF}}$ ( $\mathrm{p} 19^{\mathrm{ARF}}$ arising in major part from an alternative reading frame of the mouse INK $4 a$ gene) $[1,12,13,14]$. The locus has three regions named $1(\alpha$ and $\beta), 2$, and 3. P16 ${ }^{\mathrm{INK} 4 \mathrm{~A}}$ is composed of exons $1 \alpha, 2$, and 3 , whereas $\mathrm{P} 14^{\mathrm{ARF}}$ is composed of exons $1 \beta, 2$, and 3 (Figure 1 ). The $p 16^{I N K 4 A}$ and $p 14^{A R F}$ genes are interesting as they are both from the same locus, CDKN2A, but from different promoters.

\section{UV-MELANOMAGENESIS: THE ROLE OF THE RB PATHWAY}

Melanoma is a multifactorial disease, where both genetic and environmental sun exposure factors are involved [15]. The role of UV light in inducing CMM is a longheld belief although there is more evidence for this in the NMSC whose distribution mirrors the areas of high exposure to UV $[16,17]$. Epidemiological studies that suggested a link between sun exposure and melanoma were first published in 1956 in Australia [18]. These studies noticed that mortality from the disease increased closer to the equator. This research was extensively reviewed in 1992 by the International Agency for Research on Cancer, who definitively concluded that "there is sufficient evidence in humans for the carcinogenicity of solar radiation in causing melanoma" [19]. Retrospective epidemiological data currently suggest that unlike other skin cancers that are associated with cumulative lifetime UV exposure, $\mathrm{CMM}$ is provoked by intense intermittent exposure to UV, particularly during childhood $[5,17]$. In addition to UVB, exposure to UVA is now thought to play a part in the development of melanoma [20]. However, the functional relationship between genes and sunlight in melanoma pathogenesis is not well understood. Recently, prospects for elucidating this relationship have brightened considerably through the development of UV-responsive experimental animal models of melanoma $[21,22]$. In the skin, absorption of UV photons by the DNA of epidermal cells and the rearrangement of electrons lead to the formation of photoproducts at adjacent pyrimidine sites and unrepaired damage can lead to specific gene mutations, which are usually C to T or CC to TT, considered as "UV molecular signature" [23]. The most significant mutations induced by UV in the skin occur in tumour suppressor genes, $p 53$ and $p 16^{I N K 4 a}$ genes being the major targets of UV $[23,24]$. Recent studies using laboratory animals have identified the components of the Rb pathway (divided

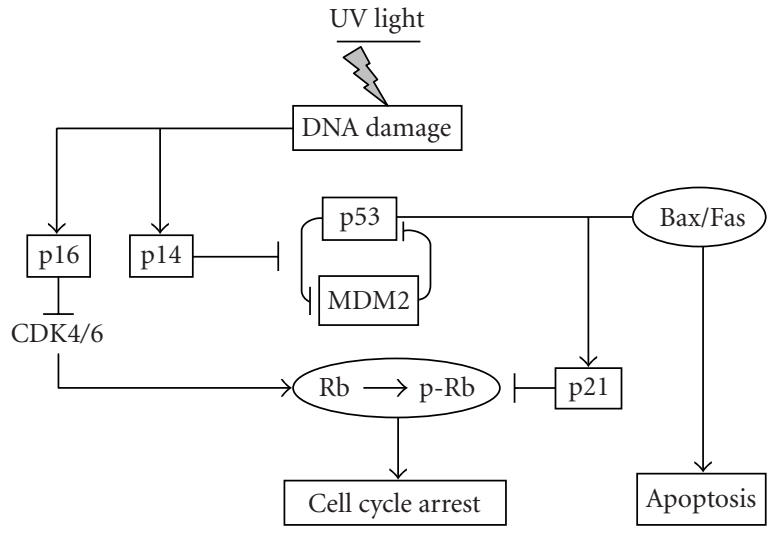

FIgURE 2. UV radiation and the components of the $\mathrm{Rb}$ pathway in the skin.

into two genetically distinct pathways: "p $16^{\mathrm{INK} 4 \mathrm{~A}} / \mathrm{Rb}$ " and "p14 $\mathrm{ARF} / \mathrm{p} 53$ ") as the main UV target(s) disrupted in the early stages of melanoma genesis [5]. However, a definitive UV-p16-melanoma relationship, and the nature of this interaction, is yet to be clarified. UV light is known to initiate a series of molecular events in the skin, acting via two distinct biochemical pathways; the p16 and p53 pathways (Figure 2).

\section{$U V$ radiation and the $P 16^{I N K 4 A}$ pathway in the skin}

$\mathrm{P} 16^{\mathrm{INK} 4 \mathrm{a}}$ is a cell cycle regulator that inhibits specifically CDK4/6 and consequently cyclin D-dependent phosphorylation of the $\mathrm{Rb}$, leading to less transcription of $E 2 F$ responsive genes necessary for $S$ phase entry (Figure 2) [25]. When p16 is induced, the Rb protein is maintained in its nonphosphorylated (active) form, E2F is not activated, and replication is halted. The relationship between p16 and melanoma has been explained by the observation that UV light can induce p16 expression in human skin $[26,27]$, thereby implying a role for $\mathrm{p} 16^{\mathrm{INK} 4 \mathrm{a}}$ in the repair of UV-induced DNA damage. In cells irradiated with low doses of UVB, P16 ${ }^{\mathrm{INK} 4 \mathrm{~A}}$ is upregulated within 1224 hours leading to a cell cycle arrest at G1 [28]. This is thought to allow DNA repair before allowing resumption of the cell cycle (Figure 2). If $\mathrm{P} 16^{\mathrm{INK} 4 \mathrm{~A}}$ is inactivated via missense mutation, deletion, or methylation [29, 30, 31], the $\mathrm{Rb}$ protein is no longer maintained in its active form and cell replication is unchecked.

The CDK4 gene, situated on chromosome 12q13 and coding for cyclin-dependent kinase 4 which binds to p16 (Figure 2), has also been identified as a melanomasusceptibility gene [32]. The CDK4 (Arg24Cys) germline mutation has been identified in melanoma-prone families $[33,34]$ and produced a mutated protein that interferes with the binding of the CDK4 protein to p16 and so prevents the inhibition of its enzymatic activity [35]. As a result, the CDK4 protein is constantly activated promoting the $\mathrm{Rb}$ pathway and subsequent cellular division. Therefore, unlike CDKN2A, the CDK4 gene functions as an oncogene [35] and not as a tumour suppressor gene. 


\section{UV radiation and the $p 53$ pathway in the skin}

The effect of UV radiation on p53 expression in the skin has been well documented (Figure 2). Using hairless mouse model, we have characterized the temporal events implicated in the immediate and adaptive responses in the skin $[36,37]$. Following acute UV irradiation of mouse skin, p53 expression increased 12 hours post-UV followed by using p21 protein to arrest the cell cycle and permit the repair of UV DNA damage [36]. If the damage is severe, apoptosis is induced in the skin (in keratinocytes and melanocytes) via p53-dependent or independent pathways $[36,38,39,40]$. To date, no direct link has been established between p53 and melanomagenesis. However, ARF (also known as p14, or p19 in mice), also a regulator of the cell cycle, has been shown to be a principal regulator of HDM2 (MDM2 in mice), an E3 ubiquitin ligase regulating p53 degradation and stability [41]. The ARF protein prevents the interaction between p53 and MDM2 and consequently p53 levels rise (Figure 2). This activates p21 which then inhibits phosphorylation of Rb, leading to cell cycle arrest in both G1 and G2. ARF is ubiquitously expressed and is elevated in cells lacking functional p53. Somatic mutations have been observed which affect the $A R F$-coding sequence exclusively $[42,43]$. If the $A R F$ gene is mutated, the events described above will be disrupted disabling ARF's tumour suppressor function that might promote melanoma development. In UV skin carcinogenesis, p53 and p16 pathways work in tandem (Figure 2), and mutations in either p16 or p53 could cause unregulated cell proliferation leading to tumour development in the skin.

\section{OTHER GENES ASSOCIATED WITH MELANOMA}

The Ras-Raf-MAPK/extracellular signal-regulated kinase signalling pathway is activated in the vast majority of melanomas (reviewed in [44]). Activation occurs through either NRAS or BRAF mutations, both of which arise early during melanoma pathogenesis and are preserved throughout tumour progression. This cascade is activated by sequential phosphorylation of a number of kinases in order to alter cellular behaviour in response to different environmental factors. The extracellular-signalregulated kinases (ERK1 and ERK2) belong to one branch of this cascade responsible for sensing extracellular stimuli, including UV light. This stimulus then activates the Ras family of proteins which then activates the RAF family of serine/threonine kinases (c-RAF 1, BRAF, and ARAF). This activation subsequently phosphorylates and activates ERK1 and ERK2. ERK phosphorylation has been linked to G-protein-coupled receptor (GPCR) signalling, as well as activation by upstream receptor tyrosine kinases (RTKs). $\mathrm{N}$-Ras mutations are found in melanomas from chronically UV-exposed sites in $26 \%$ of melanomas [45]. These proteins are stimulated at the cell membranes by epidermal growth factors causing senescence with the cells remaining in G1 phase of the cell cycle. Ras proteins also upregulate p53 via ARF [46] and p16 ${ }^{\text {INK4A }}$ protein [47]. However, although Ink4a/Arf-/- mice did not exhibit melanoma tumours [48], expression of activated H-Ras on an Ink4a/Arf-deficient background produced a high incidence of melanoma [49].

The BRAF gene encoding a serine/threonine kinase is a key component of the MAPK signalling pathway highly mutated in CMM [50]. However, although BRAF somatic missense mutations have been detected at a very high frequency in melanoma tumours, and at a lower frequency in many human cancers, this gene may not be a melanomasusceptibility gene [51]. Thus, other genes in the RasRaf-MAP kinase pathway might play a significant role in melanoma susceptibility.

\section{CONCLUSION}

Although a number of different genes have been associated with melanoma development and progression, the $C D K N 2 A$ remains the candidate gene in UV radiationinduced melanoma. The two products of this gene form the main backbone of the Rb pathway acting via two distinct pathways (Figure 2): one involving loss of the tumour suppressor gene $p 16^{I N K 4 A}$ which acts through the $\mathrm{Rb}$ protein and the other involving ARF regulating p53 degradation and stability. Both can lead to a loss of the cell cycle control following UV-induced DNA damage. Ongoing work is aiming to further elucidate the mechanisms of action of UV light on the regulation of the components of the Rb pathway and identification of novel UV-target genes involved in melanomagenesis.

\section{ACKNOWLEDGMENT}

Dr William's work was supported by the European Social Fund and the Northern Ireland Action Cancer.

\section{REFERENCES}

[1] Gilchrest BA, Eller MS, Geller AC, Yaar M. The pathogenesis of melanoma induced by ultraviolet radiation. N Engl J Med. 1999;340(17):1341-1348.

[2] Welch DR, Goldberg SF. Molecular mechanisms controlling human melanoma progression and metastasis. Pathobiology. 1997;65(6):311-330.

[3] Forrest APM, Carter DC, MacLeod IB. Principles and Practice of Surgery. 3rd ed. Edinburgh, UK: Churchill Livingstone; 1995.

[4] Bressac-de-Paillerets B, Avril MF, Chompret A, Demenais F. Genetic and environmental factors in cutaneous malignant melanoma. Biochimie. 2002;84(1):67-74.

[5] Kannan K, Sharpless NE, Xu J, O’Hagan RC, Bosenberg M, Chin L. Components of the Rb pathway are critical targets of UV mutagenesis in a murine melanoma model. Proc Natl Acad Sci USA. 2003;100(3):1221-1225. 
[6] Omholt K, Platz A, Kanter L, Ringborg U, Hansson J. NRAS and BRAF mutations arise early during melanoma pathogenesis and are preserved throughout tumor progression. Clin Cancer Res. 2003;9(17):6483-6488.

[7] Pollock PM, Trent JM. The genetics of cutaneous melanoma. Clin Lab Med. 2000;20(4):667-690.

[8] Cowan JM, Francke U. Cytogenetic analysis in melanoma and nevi. Cancer Treat Res. 1991;54:3-16.

[9] Healy E, Belgaid CE, Takata M, et al. Allelotypes of primary cutaneous melanoma and benign melanocytic nevi. Cancer Res. 1996;56(3):589-593.

[10] Castellano M, Parmiani G. Genes involved in melanoma: an overview of INK4a and other loci. Melanoma Res. 1999;9(5):421-432.

[11] Chin L, Merlino G, DePinho RA. Malignant melanoma: modern black plague and genetic black box. Genes Dev. 1998;12(22):3467-3481.

[12] Larsen CJ. p16INK4a: a gene with a dual capacity to encode unrelated proteins that inhibit cell cycle progression. Oncogene. 1996;12(10):2041-2044.

[13] Quelle DE, Zindy F, Ashmun RA, Sherr CJ. Alternative reading frames of the INK4a tumor suppressor gene encode two unrelated proteins capable of inducing cell cycle arrest. Cell. 1995;83(6): 993-1000.

[14] Sharpless NE, DePinho RA. The INK4A/ARF locus and its two gene products. Curr Opin Genet Dev. 1999;9(1):22-30.

[15] Bressac-de-Paillerets B, Avril MF, Chompret A, Demenais F. Genetic and environmental factors in cutaneous malignant melanoma. Biochimie. 2002;84(1):67-74.

[16] Fears TR, Scotto J, Schneiderman MA. Mathematical models of age and ultraviolet effects on the incidence of skin cancer among whites in the United States. Am J Epidemiol. 1977;105(5):420-427.

[17] Ley RD, Applegate LA, Padilla RS, Stuart TD. U1traviolet radiation-induced malignant melanoma in Monodelphis domestica. Photochem Photobiol. 1989;50(5):1-5.

[18] Whiteman DC, Whiteman CA, Green AC. Childhood sun exposure as a risk factor for melanoma: a systematic review of epidemiologic studies. Cancer Causes Control. 2001;12(1):69-82.

[19] IARC. Solar and Ultraviolet Radiation. vol. 55 of IARC monographs on the evaluation of carcinogenic risk to humans. Lyon: International Agency for Research on Cancer; 1992.

[20] Wang SQ, Setlow R, Berwick M, et al. Ultraviolet A and melanoma: a review. J Am Acad Dermatol. 2001;44(5):837-846.

[21] Noonan FP, Recio JA, Takayama H, et al. Neonatal sunburn and melanoma in mice. Nature. 2001;413(6853):271-272.

[22] Jhappan C, Noonan FP, Merlino G. Ultraviolet radiation and cutaneous malignant melanoma. Oncogene. 2003;22(20):3099-3112.
[23] Brash DE, Rudolph JA, Simon JA, et al. A role for sunlight in skin cancer: UV-induced p53 mutations in squamous cell carcinoma. Proc Natl Acad Sci USA. 1991;88(22):10124-10128.

[24] Peris K, Chimenti S, Fargnoli MC, Valeri P, Kerl H, Wolf P. UV fingerprint CDKN2a but no p14ARF mutations in sporadic melanomas. J Invest Dermatol. 1999;112(5):825-826.

[25] Shirodkar S, Ewen M, DeCaprio JA, Morgan J, Livingston DM, Chittenden T. The transcription factor E2F interacts with the retinoblastoma product and a p107-cyclin A complex in a cell cycle-regulated manner. Cell. 1992;68(1):157-166.

[26] Pavey S, Conroy S, Russell T, Gabrielli B. Ultraviolet radiation induces $\mathrm{p} 16 \mathrm{CDKN} 2 \mathrm{~A}$ expression in human skin. Cancer Res. 1999;59(17):4185-4189.

[27] Chazal M, Marionnet C, Michel L, et al. P16(INK4A) is implicated in both the immediate and adaptative response of human keratinocytes to UVB irradiation. Oncogene. 2002;21(17):2652-2661.

[28] Milligan A, Gabrielli BG, Clark JM, Hayward NK, Ellem KA. Involvement of p16CDKN2A in cell cycle delays after low dose UV irradiation. Mutat Res. 1998;422(1):43-53.

[29] van der Velden PA, Metzelaar-Blok JA, Bergman W, et al. Promoter hypermethylation: a common cause of reduced p16(INK4a) expression in uveal melanoma. Cancer Res. 2001;61(13):5303-5306.

[30] Castellano M, Pollock PM, Walters MK, et al. CDKN2A/p16 is inactivated in most melanoma cell lines. Cancer Res. 1997;57(21):4868-4875.

[31] Chaturvedi V, Qin JZ, Denning MF, Choubey D, Diaz MO, Nickoloff BJ. Apoptosis in proliferating, senescent, and immortalized keratinocytes. J Biol Chem. 1999;274(33):23358-23367.

[32] Ghiorzo P, Bianchi Scarr GB. Genetics of melanoma susceptibility. Forum (Genova). 2003;13(2):114-126.

[33] Zuo L, Weger J, Yang Q, et al. Germline mutations in the p16INK4a binding domain of CDK4 in familial melanoma. Nat Genet. 1996;12(1):97-99.

[34] Soufir N, Avril MF, Chompret A, et al. Prevalence of p16 and CDK4 germline mutations in 48 melanoma-prone families in France. The French Familial Melanoma Study Group. Hum Mol Genet. 1998;7(2):209-216.

[35] Wolfel T, Hauer M, Schneider J, et al. A p16INK4ainsensitive CDK4 mutant targeted by cytolytic $\mathrm{T}$ lymphocytes in a human melanoma. Science. 1995;269(5228):1281-1284.

[36] Ouhtit A, Muller HK, Davis D, Ullrich SE, McConkey D, Ananthaswamy HN. Temporal events in skin injury and the early adaptive responses in ultraviolet-irradiated mouse skin. Am J Pathol. 2000;156(1):201-207.

[37] Ouhtit A, Gorny A, Muller K, Hill LL, Owen-Schaub L, Ananthaswamy HN. Loss of Fas-ligand expression in mouse keratinocytes during UV carcinogenesis. Am J Pathol. 2000;157(6):1975-1981. 
[38] Hill LL, Ouhtit A, Loughlin S, Kripke ML, Ananthaswamy HN, Owen-Schaub LB. Fas ligand: a sensor for DNA damage critical in skin cancer etiology. Science. 1999;285(5429):898-900.

[39] Qin JZ, Chaturvedi V, Denning MF, et al. Regulation of apoptosis by p53 in UV-irradiated human epidermis, psoriatic plaques and senescent keratinocytes. Oncogene. 2002;21(19):2991-3002.

[40] Bowen AR, Hanks AN, Allen SM, Alexander A, Diedrich MJ, Grossman D. Apoptosis regulators and responses in human melanocytic and keratinocytic cells. J Invest Dermatol. 2003;120(1):48-55.

[41] Honda R, Yasuda H. Association of p19(ARF) with $\mathrm{Mdm} 2$ inhibits ubiquitin ligase activity of $\mathrm{Mdm} 2$ for tumor suppressor p53. EMBO J. 1999;18(1):22-27.

[42] Piccinin S, Doglioni C, Maestro R, et al. p16/CDKN2 and CDK4 gene mutations in sporadic melanoma development and progression. Int $J$ Cancer. 1997;74(1):26-30.

[43] Randerson-Moor JA, Harland M, Williams S, et al. A germline deletion of p14(ARF) but not CDKN2A in a melanoma-neural system tumour syndrome family. Hum Mol Genet. 2001;10(1):55-62.

[44] Chin L. The genetics of malignant melanoma: lessons from mouse and man. Nat Rev Cancer. 2003; 3(8):559-570.

[45] van Elsas A, Zerp SF, van der Flier S, et al. Relevance of ultraviolet-induced N-ras oncogene point mutations in development of primary human cutaneous melanoma. Am J Pathol. 1996;149(3):883-893.

[46] Wei W, Hemmer RM, Sedivy JM. Role of p14(ARF) in replicative and induced senescence of human fibroblasts. Mol Cell Biol. 2001;21(20):6748-6757.

[47] Benanti JA, Galloway DA. Normal human fibroblasts are resistant to RAS-induced senescence. Mol Cell Biol. 2004;24(7):2842-2852.

[48] Serrano M, Lee H, Chin L, Cordon-Cardo C, Beach D, DePinho RA. Role of the INK4a locus in tumor suppression and cell mortality. Cell. 1996;85(1):2737.

[49] Chin L, Pomerantz J, Polsky D, et al. Cooperative effects of INK4a and ras in melanoma susceptibility in vivo. Genes Dev. 1997;11(21):2822-2834.

[50] Pollock PM, Harper UL, Hansen KS, et al. High frequency of BRAF mutations in nevi. Nat Genet. 2003;33(1):19-20.

[51] Laud K, Kannengiesser C, Avril MF, et al. BRAF as a melanoma susceptibility candidate gene? Cancer Res. 2003;63(12):3061-3065.

\footnotetext{
* Corresponding author. E-mail: a.ouhtit@qub.ac.uk Fax: +44 128565 3800; Tel: +44 7766766022
} 


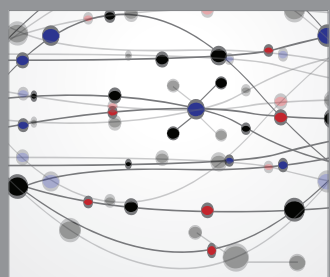

The Scientific World Journal
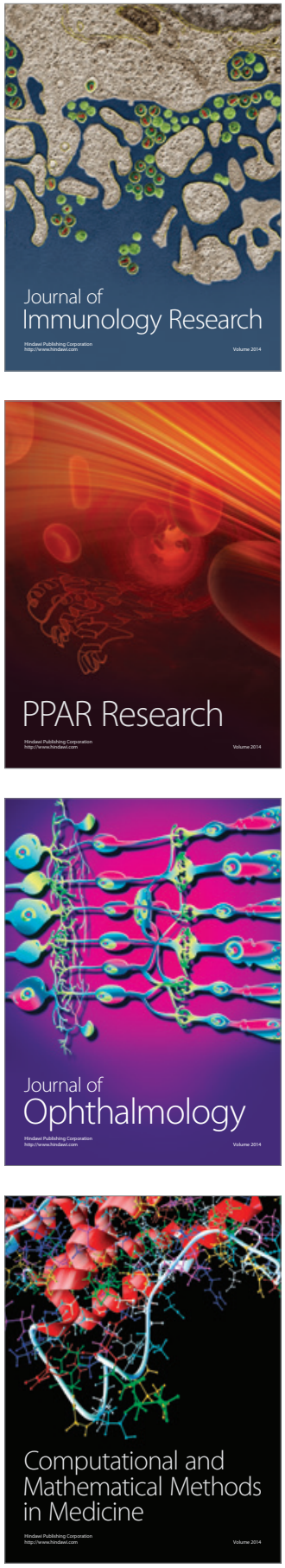

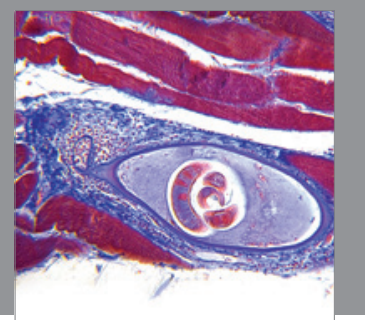

Gastroenterology

Research and Practice
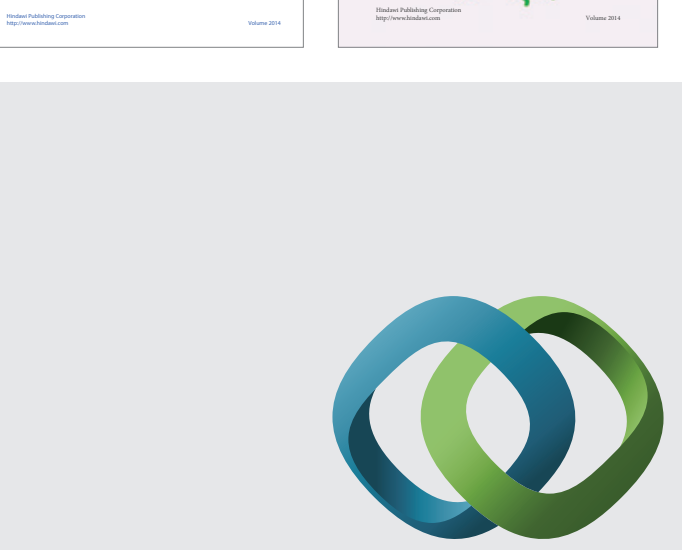

\section{Hindawi}

Submit your manuscripts at

http://www.hindawi.com
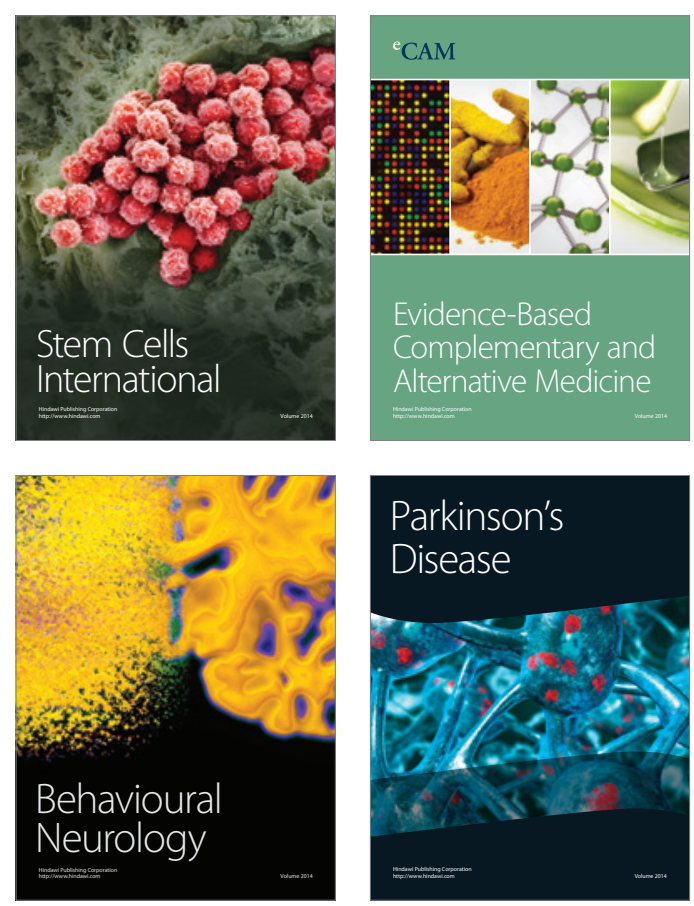

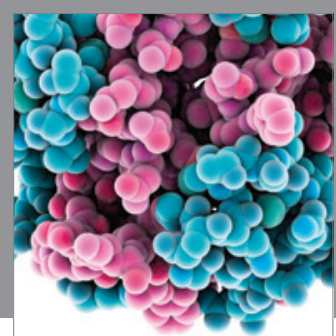

Journal of
Diabetes Research

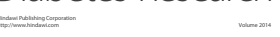

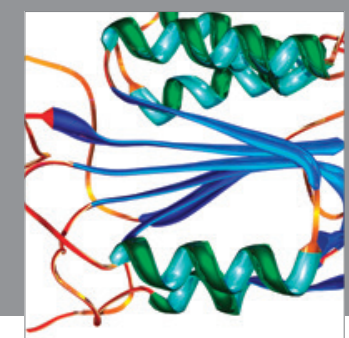

Disease Markers
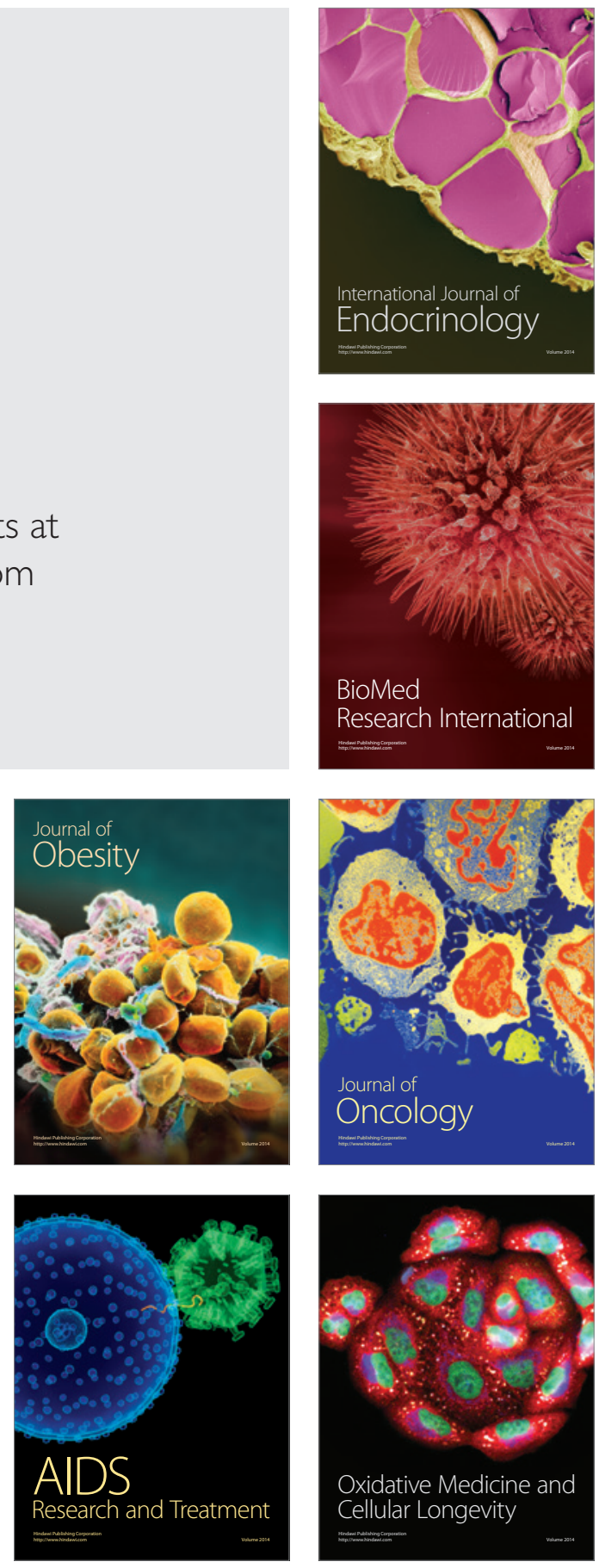